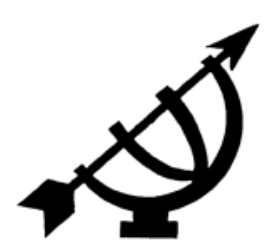

\title{
The dilemma of the failed state thesis in post-9/1 1 world affairs
}

\author{
A. Schoeman \\ Department of Political Science \\ University of the Free State \\ Qwaqwa Campus \\ PHUTHADITJHABA \\ E-mail: schoemanpa@qwa.ufs.ac.za
}

\section{Abstract \\ The dilemma of the failed state thesis in post-9/11 world affairs}

The 9/11 terrorist attacks shifted the emphasis of failed states as just a regional humanitarian problem to one that could present a global security threat. In this regard US policymakers, especially, identified failed states as possible terrorist threats. However, this renewed attention to the study of state failure has exposed a number of theoretical weaknesses in this body of literature. The latter could mainly be ascribed to the way in which US policy makers have often used generalised definitions of failed states and then applied it to states that are perceived as threats. Another problem is the fact that government sponsored research institutes and think tanks are operating independently from university academics. This situation has caused theoretical confusion as conditions in failed states are often interpreted differently resulting in the development of a number of opposing theories, definitions and confusing classification models. The body of literature is further accused of endorsing a "Weberian" definition (ideal type) of the state against which degrees of "failure" in non-complying states are measured. This article will investigate the extent of these theoretical weaknesses and expose the dangers of following an approach that seem to misinterpret the political realities of developing states (often regarded as failed) - this despite having an extensive popular following. It will further focus on possible alternative approaches - or the formulation of ideas that are better suited and relevant to the often unique internal political, social and economic dynamics of unstable states. 


\section{Opsomming}

\section{Die dilemma van die mislukte staattesis in internasionale verhoudings na 9/1 1}

Die 9/11-terroriste aanvalle het die fokus van mislukte state as bloot streeksgebonde humanitêre probleme verskuif na een wat 'n globale sekuriteitsrisiko kan inhou. Veral Amerikaanse beleidmakers het mislukte state ná hierdie insident as potensiële terroristebedreigings begin identifiseer. Die hernude belangstelling in die studie van mislukte state het egter ook 'n aantal teoretiese tekortkomings binne hierdie studieterrein blootgelê. Laasgenoemde kan toegeskryf word aan die wyse waarop veral Amerikaanse beleidmakers dikwels veralgemeende definisies van mislukte state gebruik en dit dan toepas op state wat as "misluk" beskou word. ' $n$ Verdere probleem is die feit dat regeringsgefinansierde navorsingsinstitute en dinkskrums dikwels onafhanklik van akademici by universiteite funksioneer. Hierdie stand van sake lei tot teoretiese verwardheid, aangesien toestande in mislukte state dikwels verskillend geïnterpreteer word. Die gevolg hiervan is dat teenstrydige teorieë, definisies en klassifikasiemodelle dikwels ontwikkel word. Die studieterrein word verder daarvan beskuldig dat dit 'n "Weberiaanse" (ideaaltipiese) definisie van die staat onderskryf om verskillende grade van mislukking by nie-toegeeflike state te bepaal. Hierdie artikel sal poog om die omvang van hierdie teoretiese tekortkomings te ondersoek en te fokus op die gevare van 'n benadering wat oënskynlik die politieke realiteite binne ontwikkelende state (wat dikwels as misluk beskou word) misinterpreteer. Ten slotte sal aandag geskenk word aan moontlike alternatiewe benaderings, of die formulering van idees wat meer relevant en toepaslik is vir die dikwels unieke interne politieke, sosiale en ekonomiese dinamika van onstabiele state.

\section{Introduction}

The increased interest in the "failed state" phenomenon can be traced back to events that followed the collapse of the Soviet Union in 1989 (Wesley-Smith, 2004:4-5). However, the changes that were brought about by the collapse of Communism soon exposed the vulnerabilities of weaker states across the globe. The term failed state was first coined to describe a number of humanitarian disasters that took place in the 1990s in places such as Somalia, Haiti, Cambodia, Bosnia, Kosovo, East Timor and the Great Lakes region of Africa, and particularly Rwanda (Wesley-Smith, 2004:5; Sur, 2006:1). Theorists were mainly concerned with the often tragic humanitarian consequences of state failure that included refugee pro- 
blems, displacement of people, human rights violations and genocide. The view that state failure only had domestic or regional strategic significance came to an abrupt end on 11 September, 2001 when Al-Qaeda terrorists launched devastating attacks on financial and military targets in New York and Washington, D.C.

In the aftermath of these attacks the threat of "failed states" - especially in terms of the possibility of them harbouring terrorist groups - was seemingly popularised by US policymakers to justify its "war on terror". This has focused renewed attention and interest in the study of state failure but has also exposed a number of theoretical weaknesses in this body of literature. US policymakers, for instance, seem to use a generalised definition of failed states which is then just arbitrarily applied to states perceived as security threats. The failed state literature is also divided by mainly government sponsored research institutes and think tanks that operate independently from academics at universities. The views of these two camps are often contradicting which causes further theoretical confusion. Despite this, state leaders, governments and non-governmental agencies seem to rely strongly on the findings of failed state theorists and think tanks to make policy decisions. This article will investigate the extent of these theoretical weaknesses and expose the dangers of following an approach that seem to misinterpret the political realities of developing states (often regarded as failed) - this despite having an extensive popular following. It will further focus on possible alternative approaches - or the formulation of ideas that are better suited and relevant to the often unique internal political, social and economic dynamics of unstable states.

This article will commence by briefly focusing on a Western "Weberian" approach to the state as the theoretical point of departure. Thereafter emphasis will be placed on the failed state thesis' endorsement of this view as the benchmark (ideal type state) against which conditions in failed states are measured. Criticism against the apparent theoretical weaknesses in this body of literature will then receive attention. After a brief defence of the failed state thesis' endorsement of the "Weberian" ideal-type state, emphasis will be placed on possible theoretical alternatives to those that are currently offered by this body of literature.

\section{The "Weberian" state - a brief conceptualisation}

In the words of Heywood (2002:86) the term state has been used "... to refer to a bewildering range of things: a collection of institutions, a territorial unit, a philosophical idea, an instrument of 
coercion or oppression and so on". One of the reasons for this confusion seems to be the fact that the state has been understood from idealistic, functionalist and organisational perpectives. For the purposes of this article the author adheres to elements of both the functionalist and organisational approaches to the state. In terms of the first, focus is placed on the role and purpose of state institutions with particular emphasis on the state as a set of institutions that has to guarantee order and deliver social stability. In terms of the organisational perspective the state is broadly perceived as the apparatus of government or the set of institutions that are "public" because they are responsible for the collective organisation of social existence. A clear distinction is therefore made between the state and civil society. According to this view the state comprises the various institutions of government which includes the bureaucracy, the military, the police, the courts as well as the social security system.

Some of the characteristics of organisational perspective can be traced back to fifteenth and sixteenth century Europe when centralised rule succeeded in subordinating all other institutions and groups. The modern nation state came into being with the signing of the Peace Treaties of Westphalia in 1648. These treaties laid down the basic rules of what would later become the requirements of statehood. By adhering to these requirements, states were not only recognised by other states as equal but they also earned the right to rule over their particular territories without interference from other states (Scholte, 1999:19-21; Heywood, 2002:86). A permanent population living within the confines of a demarcated territory with a sovereign government became the key requirements and characteristics of the modern state. (Compare the definitions of Frost, 1997:1-18; Jackson \& Jackson, 1997:34-35; and Vincent, 2004:40.) However, in arguably the most influential definition Max Weber (quoted in Jackson \& Rosberg, 1982:2) describes the state as a

... corporate group that has compulsory jurisdiction, exercises continuous organization, and claims a monopoly of force over a territory and its population including all action taking place in the area of its jurisdiction.

By focusing on a government's ability to use force within its territory, Weber emphasises the empirical (de facto), rather than the juridical (de jure) attributes of statehood. The main point of departure in the definition of Weber is whether the state has the ability to exercise the overwhelming monopoly of force within its territorial jurisdiction. 
Under the influence of, and elaborating on, the Weberian definition, Migdal (1988:19) defines what he calls a "strong state" (also interpreted as an ideal type state) as

... an organization composed of various agencies led and coordinated by the state's leadership (executive authority) that has the ability or authority to make and implement the binding rules for all the people as well as the parameters of rule making for other social organizations in a given territory, using force if necessary to have it's way.

He defines the capabilities a state should possess and then compares Third World states to that definition. A state's capabilities would include the capacity to penetrate society, regulate social relations, the ability to extract resources as well as the use and effective distribution of these resources. In his view strong states possessed high capabilities to complete these tasks while weak states were placed on the low end of the spectrum of capabilities. In both these definitions (with a strong institutional focus), emphasis is placed on state capacity or the state's ability to provide order and state services or public goods such as health, education, infrastructure, social services, an efficient labour market and a healthy environment among many other things (Speiser \& Handy, 2005:11).

In fulfilling these duties the state must play a minimal role (characteristic of a minimal state) in that it must merely act as a protective body, with the task of providing a framework of peace and social order in which its citizens can live up to their full potential. The state should only be called upon when orderly existence is threatened. It must therefore fulfil the role of a "referee" that has the ability to protect each citizen from the encroachments of fellow citizens. From this pluralist perspective the state is seen as neutral and acts in the interest of all citizens. It represents the common good or public interest (Heywood, 2002:88-89).

The Weberian definition of the state, with its strong emphasis on state capacity and upholding law and order has found favourable expression within a liberal democratic political system (regime). Different ways of ordering state power, that is, democratic, totalitarian and authoritarian, are indicative of distinctive regime types (Du Toit, 1995:28-29). Political regimes are further described by Bratton and Van de Walle (1997:9-10) as sets of political procedures - often referred to as the "rules of the game" - that determine the distribution of political power. In this regard Joseph Schumpeter (1947:269) refers to democracy as “... a system for arriving at poli- 
tical decisions in which individuals acquire the power to decide by means of a competitive struggle for the people's vote". This further implicates civil and political liberties such as freedom of speech, the right to publish and the right to organise public meetings. A liberal democratic system further needs to adhere to the principles of "good governance", the rule of law and the protection of human rights. In the following section focus will be placed on how the Weberian definition of the state has been embraced by the "failed state thesis" as their theoretical point of departure.

\section{The failed state thesis and the "Weberian ideal type" state}

According to Hill (2005:144-145) the failed state thesis refers to an explanation about socio-political crisis as well as the body of literature in which this argument is developed and promoted. In short:

The principle aims of the literature therefore, are to investigate and explain why state failure occurs; to outline and identify ways of identifying failed states; to identify states that are failed or are in danger of failing; to describe the processes of failure; and to consider how state failure can be either prevented or reversed. (Hill, 2005:145.)

In their attempts to address the aforementioned aims, this body of literature has developed the notion of an "ideal-type" (or strong) state against which conditions in "failed states" are measured. In defining such an ideal-type state Eriksen (2006:2-6) identifies two different approaches to state failure (based on their proponent's understanding of the state). The most prominent of these approaches finds its inspiration in the Weberian definition of the state discussed in the previous section. Emphasis is strongly placed on the state's ability to maintain order within its jurisdiction through the use of legitimate force. Can the state therefore guarantee a safe environment for its population and does it have firm political control over its whole territory? In failed states, governments often control only part of its territory (usually the capital) while other parts are controlled by different factions. In other words, the state loses physical control over its territory (Williams, 2007:1-2). Recent incidences of piracy of the Somali coast serve as an example of how ruling factions have turned to lawlessness and criminality in the absence of a strong government that is supposed to guarantee order and exercise firm control over its territory (Kraska \& Wilson, 2008/2009:41-52). In such an environment the government is also unable to provide security to its whole population. Jackson (2000:296) adds that failed states are 
unable or refuse to safeguard minimal civil conditions for their citizens such as domestic peace, law and order and good governance. In fact, most postcolonial states lack positive sovereignty (empirical statehood), or the ability to control their territory, may have to deal with armed insurgents and have little ability to implement policies or promote economic development. Despite this, these states persist and continue to be recognised as equal participants in the state system. Jackson (1990) describe these entities as quasi-states. Woodward (2004:2) adds that state failure becomes almost inevitable when there is "... a credible challenge to the monopoly over the legitimate use of force or its outright loss of that monopoly". States that are therefore not able to accomplish the latter are regarded as failed.

The second underlying, or Lockean approach, is supported by authors such as William Zartman (1995) and Robert I. Rotberg (2003) who interpret the role of the state as that of a service provider. In this view states collapse when the latter can no longer provide the services for which it exists. Apart from the fact that it is expected of the state to provide security for its citizens it is also the state's duty to deliver other public goods in a variety of social sectors. These services include health, education, infrastructure, social services, an efficient labour market and a healthy environment among many other things. It is further expected of the state to provide transparent mechanisms for the redistribution of economic resources. In terms of the second approach failure is commonly used to highlight the way in which a state, either because of lack of capacity or a lack of political will, fail to provide public goods to the entire population instead of just a segment of it.

In an attempt to determine the degrees to which different (weak) states are unable to comply to the minimum requirements of statehood a number of scholars such as Geldenhuys (1999), Rotberg (2002) and Gros (1996) have developed classification models in which the degrees of deterioration in these states are measured against conditions in an ideal-type state (referring to Weber's definitions of the state). This approach gauges degrees of stateness along a continuum starting with those states that meet classical Weberian criteria of statehood and ending with those that meet none of these criteria of successful statehood. The closer a state comes to fulfilling the ideals of statehood the closer its position will be to the ideal-type state indicating that it experiences a lesser degree of failure. States that have a limited or no capacity to fulfil the requirements of statehood are placed further away from the ideal-type state 
indicating higher degrees of deterioration. In spite of slight differences, most of the classification models distinguish between a number of broad categories of failed states namely soft, weak, failing, failed and collapsed states. In the following section attention will be given to criticism against the supposedly weak theoretical foundations the failed state thesis is constructed on.

\section{A critique of the failed state thesis}

\subsection{Failed states as terrorist havens}

In the aftermath of September eleventh's terrorist attacks the strategic impact of state failure has shifted from a regional (and limited) to a global threat (Helman \& Ratner, 1993:3-20; Raeymakers, 2005:3). The term failed state was popularised for the first time in the New National Security Strategy, a foreign policy document released in 2002 by the United States government in reaction to the 9/11 terrorist attacks. Failed states were identified as a serious national security threat, linking it to the proliferation of weapons of mass destruction, criminal networks and of course terrorism (Wise, 2004:7; Takeyh \& Gvodsev, 2003:96). According to Rice (2003:2) the National Security Strategy (NSS) particularly focused on the threat that failed states posed in terms of providing "safe havens" for terrorist organisations. Dunlap (2007:3) argues that failed states are currently a major concern for analysts and policymakers for three reasons. Firstly, because of the chaos and lawlessness that exist in these societies terrorist organisations can conduct their activities without fear of capture or punishment. In the second place, failed states often provide terrorist groups with access to all the necessary resources they need to conduct their activities, including money and recruits. In the third place, failed states provide terrorist groups with the protection of their sovereignty (Takeyh \& Gvodsev, 2003:7-8).

Despite its seemingly dominant position in world affairs, the ("mostly American") perspective that failed states provide terrorist havens has been challenged by a body of literature that include among others the contributions of Patrick (2006); Mills (2004:157-169); Von Hippel (2002:25-39) and Logan and Preble (2006). Patrick (2006:3435) argues that the connection between state weakness and transnational terrorism is more complicated and tenuous than often assumed. Firstly, not all weak or failed states are characterised or afflicted by terrorism. In the 49 countries that have recently been categorised by the United Nations as the least developed, hardly any terrorist activity occurs. The lack or absence of state capacity (often regarded as a key characteristic of state failure) per se is 
unable to explain why terrorist activity is concentrated in specific regions, particularly the Middle East and broader Muslim world instead of other regions such as Central Africa. Secondly, not all acts of terrorism that occur in weak and failing states are transnational. This is illustrated by the fact that much of these terrorist acts are self-contained action by insurgents motivated by local political grievances or national liberation struggles such as the Liberation Tigers of Tamil Eelam (LTTE) in Sri Lanka (Patrick, 2006:34; Mills, 2004:157-169). Thirdly, in terms of the degrees of failure that they experience, not all weak and failing states are equal. Adherents to the failed state thesis are fond of arguing that terrorists are attracted to collapsed, lawless polities such as Somalia or Liberia. On the contrary, terrorists are often more likely to use weak but functioning states such as Pakistan or Kenya as their organisational bases (Patrick, 2006:35; Mills, 2004:161-162).

Observers such as Logan and Preble (2006:6) go so far as to argue that the United States is just arbitrarily linking acts of terrorism to a very generalised definition of failed states as justification to drive its war on terror. The US government should, instead of issuing categorical statements about who or what they perceive to be failed states, rather examine countries, failed or otherwise, on the basis of discrete measures of threat assessment: to determine the intentions of governments and non-governmental organisations in terms of attacking the United States. Empirical data on failed states have proven that state failure rarely translates into security threats to the United States. It is therefore argued that the United States is committing "strategic overkill" by exaggerating the global terrorist threat posed by failed states. It relies on a generalised definition of state failure (often not even distinguishing between weak, failing or collapsed states) without making a thorough analysis of the unique political, cultural, religious and economic dynamics that exist in these states. However, it would be unfair to hold failed state theorists responsible for the apparent ideological misuse of its analytical approach by US policymakers just as it would be ridiculous to hold Karl Marx's ideas responsible for the misconduct of Joseph Stalin. Regardless of this, a number of theoretical shortcomings have been identified by critics of the failed state thesis.

\subsection{Weak theoretical foundations}

The general concern about the apparent theoretical weakness of the failed state thesis is summarised by Woodward (2004:5) who argues that it has generated 
...very bad or superficial research. The measures are abysmal, the studies are tautological (the exact same empirical measures are used for both cause and outcome), and there is no real effort at causal analysis, identifying the causal links between state fragility and these outcomes of concern.

In this regard two theoretical weaknesses can be identified.

\subsubsection{Failure of the concept as an analytical category}

Commentators such as Doornbos (2002:797-815) and Milliken and Krause (2002:1-21) have suggested that the literature on state failure and collapse suffer from a number of dangerous flaws. Not only is it littered with obscure definitions but the causes and consequence of the concept tends to be blurred. These flaws and obscurities have become painfully apparent where different categories of polities such as quasi, weak, failed, failing, flawed, fragile and collapsed have been used by different observers as if their meanings are exactly the same. Words such as weak and failed are for instance used interchangeably to describe conditions in states that might actually be collapsing. According to Woodward (2004:4) the situation is further complicated by the fact that the failed state concept represented a coming together of humanitarian, human rights, development and security perspectives (or distinct academic communities) although the term held different meanings to each of these perspectives. This problem can probably be ascribed to the fact that much of the current literature on state failure no longer comes from university departments but purposely set up government funded research institutes and think tanks that function in most instances separately from academic institutions. In terms of their understanding and interpretation of the concept, none of these perspectives seem to share common ground and further appear to be speaking past each other (Hameiri, 2007:124).

Woodward (2004:4) adds that the term failed state is not defined in a way that makes it possible to analyse empirically. The definition of the term is not only vague but also just a list of characteristics and assumed consequences. Many observers and policy orientated projects within this body of literature have attempted to formulate indicators that are intuitively logical and supposed to be widely shared among "failed" states. 1 It is assumed that one or all of these

1 In his work When states fail: causes and consequences, Robert I. Rotberg (2004:5) compiles a list of possible indicators of state failure that includes civil wars, disharmony between communities, loss of control over peripheral regions, 
indicators can be observed in these states. The term failed state is regarded as self evident and applied to specific cases. Diverse states (as mentioned above) are characterised as failed states almost by academic endorsement. Conditions in these states (however different they might be) are taken to be evidence of what is left more or less unexplained. Even in academic journals that aspire to theoretical excellence and rigor, the concept tends to crash into impressionist description. According to Call (2006:7-8) observers have often attempted to apply a single remedy to states in which "symptoms" ranging from poverty to civil war, can be identified, hoping that such a remedy would be able to cure all problems.

\subsubsection{Inability to explain}

According to Gourevitch (2005:6-9) the failed state thesis attributes state failure to the inappropriateness of the state or sovereignty as a norm. The state is regarded as an artificial import or coercive imposition on societies (mostly states in the Third World) unfit for that kind of political organisation. By arbitrarily drawing political boundaries around diverse ethnic identities, it forced together incompatible political communities. Because of their lack of understanding of the dynamics of domestic politics, failed state theorists have tended to identify ethnicity and ethnic conflict as a logical given which would make the possibility of creating national unity highly unlikely. To them the breakdown of state institutions was inevitable due to these divisions (Rotberg, 2004; Herbst, 2000:106-112). Sovereignty is perceived just as negatively, specifically because of the argument that failed state's juridical statehood was legally protected at the expense of developing effective empirical statehood. States no longer had to prove empirical capacity, as was the situation under the pre-UN dispensation, in order to obtain international legal status. Governments in these states could abuse this right in order to commit atrocities and enrich themselves at the expense of their populations. The needs of the local populations could no longer be met by these states and political autonomy no longer had any material justification (Gourevitch, 2005:7-8; Jackson, 1990:21-31; Eriksen, 2006:4-6).

growth in criminal violence, cessation of functioning legislatures and judiciaries, informal privatisation of education, health and other social services, loss of legitimacy and declining per capita GDP. Broadly the same criteria are also identified in the annual Failed State Index produced by the Fund for Peace in Foreign Policy journal (Failed State Index, 2008:64-68). 
Focus is further placed on the chaos and anarchy that has supposedly contaminated the whole state instead of for instance, government institutions that is but one component of the state. Observers within the failed state literature have an obsession with the supposed internal chaos and disorder that seems to be at the order of the day in these states (also compare the contribution of Kaplan, 1994:40-76). However, there are profound differences between anarchy defined as the absence of government institutions and the actual breakdown of indigenous social structures. Instead of focusing on the collapse of a specific set of institutions it is argued that the state itself has collapsed. The fact that the state itself has somehow failed is supposed to be novel in comparison to other historical political conditions such as revolutions, civil wars, wars of secession or wars of national liberation. Where comparative politics used to make distinctions between revolutions, civil wars and wars of secession, these political crises are assimilated under the broad church of anarchy because they are manifestations of one thing: disorder. Because of the view that "domestic anarchy" is responsible for state failure, it implies that policymakers do not have to understand the local dynamics that drive a conflict, nor recognise specific groups as legitimate actors in the conflict. Instead the situation can merely be treated as chaos, which a disinterested third party can resolve with the proper policy instruments. It is therefore tailored more to Western priorities than domestic reality (Gourevitch, 2005:4).

The inability of failed state theorists to explain the intricate internal social dynamics of states (that they perceive as failed and racked by disorder) is, in a twist of irony, due to their weak theoretical understanding of the state. Their inability to separate conceptually between institutions that serve certain purposes (such as government, security or welfare) and the state as a whole is symptomatic of this (also compare the views of Rotberg, 2004; Zartman, 1995). The state can not be described as just a set of institutions but rather a specific kind of relationship between these institutions and society. Only when they are derived from the will of the governed can these institutions become state institutions. The state further comprises those institutions that are materialisations of sovereign political power; it is the sovereign that instantiates its power and purposes in institutions. In terms of this explanation a "strong" state with the institutional capacity to repress may in fact be "weaker" in the sense of lacking any basis in their society (also compare the contribution of Demetriou, 2003:106-108). The collapse of certain institutions (for instance an absolute monarchy) may be a precondition for establishing the state on a new social basis, rather than a sign of 
failure. Throughout history, periods of crisis (such as revolutions and civil war) have marked shifts like these in society as well as transformations in the relations between state and society (Gourevitch, 2005:13).

\subsection{Normative model of the state}

Woodward (2004:5) is of the opinion that the failed state literature tends to base their arguments on a particular normative model of the state - in this regard a free market orientated liberal democratic state that is transparent and accountable and further possesses very specific institutional requirements. In terms of the latter, the state is, for instance, required to guarantee and uphold the monopoly over the legitimate use of violence and provide a number of essential services (see the section on the conceptualisation of the failed state thesis). It is therefore nothing more than a value-based notion about what the state is supposed to be and a patronising approach to scoring states based on their abilities to adhere to those values. The extent of the inability to comply with the latter will determine degrees of failure whether that is weak, failed or collapsed (Call, 2006:11; Eriksen, 2006:4). However, very few Western states have the ability to fulfil all the requirements of statehood as prescribed by the ideal type standard. If these requirements of statehood had to be applied strictly, most Western states would also display signs of state failure! The capabilities of mostly postcolonial states are therefore compared with states in the West. The strengths, successes, weaknesses and failures of states are simplistically reduced to an empirically observable capacity to manipulate coercive resources resulting in an antidemocratic overtone of control and subordination (Bilgin \& Morton, 2002:62-63).

Hill (2004:8) and Dolek (2005:2) contend that the supposed deviancy of failed states from Western norms is expressed in language, imagery and analogies used to describe them (failed states). Conditions in failed states are often perceived as similar to an "illness" in comparison to "healthy" Western states. In extreme cases commentators even go so far as using terminology of psychoanalysis to describe conditions in failed states. This comparison thus entails a neglect of history, demography, culture and economics and their relationship to regional dynamics and patterns. In this case it is almost like comparing apples and oranges. However, in spite of the criticism it has received, the use of a Western statecentric approach has also been defended by failed state theorists. 
Call (2006:6) is adamant that the failed state thesis has made some positive contributions by helping to "... advance research, resources, and policy attention to states which are not serving their populations". This body of literature justifies its use of a statecentric approach on the basis that no other form of social organisation has ever succeeded in replacing the state, nor has any other form been as comprehensive in terms of its characteristics and function. The "ideal type" state remains the only standard against which conditions in other states can be measured. In addition Eriksen (2006:7-8) provides three reasons why theories of liberal democratic Western states (ideal type state used by the failed state thesis) are relevant for understanding non-Western states (which is often characterised as failed). Firstly, it must be acknowledged that the formal institutions of all states are constructed on the European model of statehood. Although institutions (such as courts, parliaments and bureaucracies) in postcolonial states have been imported in the sense that they originate from Europe, they nevertheless remain the basis for all contemporary states. Secondly, regardless of whether states are Western or non-Western, they all form part of the global system of states. The modern state form is, therefore, universally recognised as the fundamental political unit. In view of the universal acceptance of this notion of statehood, even states that do not possess these defining features of statehood are recognised on the presumption that they do possess them. Thirdly, when focus is placed on social scientific analysis, one is compelled to use the language of that science which, in this case, happens to be Western in origin. This, however, does not imply that there are no differences between Western and non-Western states or that theoretical models based on Western ideas and conceptions must be applied uncritically in all contexts (Eriksen, 2006:7-8).

\section{Alternatives to the failed state thesis?}

Eriksen (2006:8) concludes that the Western notion of statehood is indispensable. What is, however, problematic with the failed state thesis is not that it employs concepts derived from theories of Western origin, but rather which Western concepts it applies and how. For instance, commentators such as Zartman (1995), Rotberg (2003) and Jackson (1990) use a specific idealised notion of statehood (ideal type state) which is used as a yardstick from which deviations are measured. Call (2006:12-17) is adamant that if one accepts the deficiencies of the failed state concept an appropriate alternative response need to be developed. Although he admits that the suggestions are tentative and normative they do reflect $a$ 
reaction against the deficiencies of the failed state concept (as discussed above). Additional research is needed which suggests that a vast new field of study might be possible.

A major problem with the failed state thesis is its narrow focus on states and state strength which often leads to crude and clumsy policy responses. It is imperative to rather develop tailored policy responses to specific contexts. By making use of a more contextualised approach the underlying and proximate causes of, for instance, armed conflict can be better analysed. In terms of the latter a more anthropological approach is suggested as an alternative to the more state centered one. For external actors (donors, diplomats, development specialists and peacekeepers) such an approach

... devises strategies based on the past trajectory and eschews reliance on any external model. Each strategy is ideally sui generis, reflecting none of the biases inherent in drawing on the models of other countries, far or near (Call, 2006:12-13).

Call (2006:14-17) further suggests that the classification system used by the failed state thesis (in terms of which states are classified as weak, failed and collapsed) needs to be revised. New categories of states need to be developed which would provide more objective reflections of conditions and circumstances in the states under discussion. Eriksen (2006:8-10) adds that if an ideal type model of the state is used the latter must be adapted in such a way as to reflect the internal conditions in the alleged failed states. This implies that an ideal type of the modern state that is derived from the properties of mostly liberal democratic Western states cannot be used to analyse states that deviate significantly from the ideal type. This further implies that a different ideal type (or perhaps several different ideal types) based on the properties of the state in question need to be developed. As a rather extreme example the neo-patrimonial state is, for instance, suggested as a possible alternative ideal type. In the latter system there is no clear separation between private and public interests and public resources are often utilised for private purposes. It is also hard to distinguish between the personal interests of officials and the interests of the institutions to which they belong. In response Call (2006:14-17) suggests a further five possible categories of states which are also better aligned to the anthropological approach discussed earlier. These categories include weak states (with a weak formal institutional capacity), divided states (which might possess strong institutional capacities but is only functioning effectively in certain portions of its territory), wartime states and postwartime states (characterised by armed conflicts), 
semi-stable authoritarian regimes (which comes to power through violence and are then able to establish sufficient coercive control to repress the opposition), and collapsed states (the absence of any national-level authority to which either internal social actors or external actors could turn).

Although the above-mentioned categories might be considered an improvement on the neo-patrimonial ideal type, some of the ills of the failed state classification models seem to be repeated here. Despite moving away from using a liberal democratic Western ideal type state model and focusing more strongly on the unique social and political dynamics of individual troubled states, the Call (2006) classification is still guilty of formulating generalised categories based on a number of possible variables that might occur in these states. Conditions in a specific state may, for instance, only partly fit a category or might not be able to fit into any of the categories. In other states, overlaps, in terms of conditions, between different categories might also occur. This approach is, for instance, still unable to explain and classify states in which secessionist factions are able to control important areas (often mineral rich) and sustain themselves through transborder and international commercial linkages, independent of the ruling government (for instance Unita in Angola and the Nkunda faction in the DRC). These alternative approaches therefore need to be further refined if there is any hope of them replacing the dominant and popular classification models of the failed state thesis. Although the latter has obvious theoretical flaws very few scholars have criticised, or even suggested alternatives to the current failed state discourse. In terms of this article, for instance, only two failed state critics have suggested and formulated alternative approaches. If, as Woodward (2004:5) has suggested, the failed state thesis has generated "... very bad or superficial research", there is a need to either replace the whole discourse or to revise its theoretical basis in such a way as to provide a more objective analysis of political and social conditions in the developing world. A new classification model, which is more reflective of the unique social dynamics of troubled states, will need to be developed. For the same reason the normative and Western-centric theoretical approach of the failed state thesis is also in need of urgent revision. For this to be successfully accomplished more adherents to the failed state thesis need to be convinced of its theoretical weaknesses, but also encouraged to contribute towards formulating feasible alternatives. 


\section{Concluding remarks}

The 9/11 terrorist attacks has shifted the emphasis of failed states as just a regional humanitarian problem to one that could present a global security threat. In this regard US policymakers, especially, identified failed states as possible terrorist threats. However, this renewed attention to the study of state failure has exposed a number of theoretical weaknesses in this body of literature. The latter could mainly be ascribed to the way in which US policymakers have often used generalised definitions of failed states and then applied it to states that were perceived as threats. Another problem is the fact that the failed state thesis is not a coherent body of literature but that it consists of university academics on the one hand and government funded research institutes and think tanks on the other. This situation has caused theoretical confusion as conditions in failed states are interpreted differently by the two camps. This has further resulted in the development of a number of different theories, definitions and confusion classification models. The body of literature has further been accused of adhering to a Western (Weberian) ideal type state against which conditions in all other states (Western and non-Western) are compared and measured. States that do not comply are classified according to the degrees of non-compliance (failure). This position has, however, been defended on the basis that no other form of social organisation has been able to replace the state. If state failure is studied the state (ideal type) can be the only benchmark or measure to compare conditions in other states. Most studies of state failure reflect strong Western sentiments and approaches. It is therefore logical that the use of a Western ideal type state would be prominent. However, stronger emphasis needs to be focused on the contributions of non-Western approaches towards state failure.

The study concluded with an emphasis on possible alternative approaches to those presented by the failed state thesis. Interestingly, among all the contributions of critics of the failed state approach in this article only two (Call, 2006; Eriksen, 2006) suggested alternatives. Furthermore, very few contributions were critical of the failed state theory in comparison to the literary thousands of adherents to this body of literature. Both contributors (Call and Eriksen) suggest that, in terms of an alternative approach, a form of ideal type model of the state will still need to be utilised although it had to be revised. The Western notion of statehood remained indispensable as long as new categories of states were developed which would provide a more objective reflection of conditions and circum- 
stances in the states under discussion. In both these alternative approaches the contributors provided new classifications of states based on circumstances they believed were more reflective of conditions in developing states. However, these alternative approaches also seemed as vulnerable to criticism as the failed state classification models. This suggested that there was still quite a way to go in terms of developing an effective alternative to the dominant failed state thesis. This, however, opened up the possibilities for developing a whole new field of study.

\section{List of references}

BILGIN, P. \& MORTON, A.D. 2002. Historicising representations of "failed states": beyond the cold-war annexation of the social sciences? Third world quarterly, 23(1):55-80.

BRATTON, M. \& VAN DE WALLE, N. 1997. Democratic experiments in Africa: regime transitions in comparative perspective. Cambridge: Cambridge University Press.

CALL, C.T. 2006. The fallacy of the failed state. Paper presented at the International Studies Association Annual Meeting, San Diego, California.

DEMETRIOU, S. 2003. Rising from the ashes? The difficult (re)birth of the Georgian State. (In Milliken, J., ed. State failure, collapse \& reconstruction. Oxford: Blackwell. p. 105-129.)

DOLEK, C. 2005. The myth of "failed state" in Africa: a question on atomistic social ontology? http://www.turkishweekly.net/printerfriendly/printerfriendly. php?type=comments\&id=2887 Date of access: 8 Jul. 2008.

DOORNBOS, M. 2002. State collapse and fresh starts: some critical reflections. Development and change, 33(5):797-815.

DU TOIT, P. 1995. State building \& democracy in Southern Africa: a comparative study of Botswana, South Africa and Botswana. Pretoria: HSRC.

DUNLAP, B.N. 2007. State failure and the use of force in the age of global terror. http://www.bc.edu/schools/law//lawreviews/metaelements/journals/ bciclr/27_2/09_TXT.htm Date of access: 19 Jul. 2009.

ERIKSEN, S.S. 2006 . The theory of failure and the failure of theory: "state failure" in theory and practice. Paper presented at a Conference of the International Peace Research Institute (PRIO) and the Norwegian Institute of International Affairs held in Oslo, Norway.

FAILED STATE INDEX. 2008. Foreign policy, (167):64-68.

FROST, M. 1997. What is Politics? (In Johnson, A., Christie, K., Frost, M. \& Grest, J., eds. Politics: a beginners text. Cape Town: Juta. p. 1-18.)

GELDENHUYS, D. 1999. Staatsverval. Politeia, 18(2):37-54.

GOUREVITCH, A. 2005. The myth of the failed state. Paper prepared for a conference of the International Studies Association. New York: Columbia University.

GROS, J.G. 1996. Towards a taxonomy of failed states in the new world order: decaying Somalia, Liberia, Rwanda and Hiati. Third world quarterly, 17(3):455-471. 
HAMEIRI, S. 2007. Failed states or failed paradigm? State capacity and the limits of institutionalism. Journal of international relations and development, 10(2):122-149.

HELMAN, G.B. \& RATNER, S.R. 1993. Saving failed states. Foreign policy, (89):3-20.

HERBST, J. 2000. States and power in Africa: comparative lessons in authority and control. Princeton: Princeton University Press.

HEYWOOD, A. 2002. Politics. Houndsmills: Macmillan.

HILL, J. 2004. Challenging the failed state thesis. The Centre for International Politics Working Paper. Manchester: University of Manchester.

HILL, J. 2005. Beyond the other? A postcolonial critique of the failed state thesis. African identities, 3(2):139-154.

JACKSON, R. 2000. The global govenant: human conduct in a world of states. Oxford: Oxford University Press.

JACKSON, R.H. 1990. Quasi-states: sovereignty, international relations and the third world. Cambridge: Cambridge University Press.

JACKSON, R.H. \& ROSBERG, C.G. 1982. Why Africa's weak states persist: the empirical and juridical in statehood. World politics, 35(1):1-24.

JACKSON, R.J. \& JACKSON, D. 1997. A comparative introduction to political science. New Jersey: Prentice Hall.

KAPLAN, R. 1994. The coming anarchy: how scarcity, crime, overpopulation, tribalism and disease are rapidly destroying the social fabric of our planet. The Atlantic monthly, 273:44-65, Feb.

KRASKA, J. \& WILSON, B. 2008/2009. Fighting pirates: the pen and the sword. World policy journal, 25(4):41-52.

LOGAN, J. \& PREBLE, C. 2006. Failed states and flawed logic: the case against a standing nation-building office. Washington DC.: Cato Institute. (Policy analysis, No. 560.)

MIGDAL, J.S. 1988. Strong societies and weak states: state society relations and state capabilities in the third world. New Jersey: Princeton University Press.

MILLIKEN, J. \& KRAUSE, K. 2003. State failure, state collapse, and state reconstruction: concepts, lessons and strategies. (In Milliken, J., ed. State failure, collapse \& reconstruction. Oxford: Blackwell. p. 1-21.)

MILLS, G. 2004. Africa's new strategic significance. The Washington quarterly, 27(4):157-169.

PATRICK, S. 2006. Weak states and global threats: fact or fiction? The Washington quarterly, 29(2):27-53.

RAEYMAEKERS, T. 2005. Collapse or order? Questioning state collapse in Africa. Brighton: University of Sussex. (HiCN Working Paper, 10.)

RICE, S.E. 2003. The new national security strategy: focus on failed states. Washington: The Brooking Institution. (Policy Brief, 116.)

ROTBERG, R.I. 2002. The new nature of nation-state failure. The Washington quarterly, 25(3):85-96.

ROTBERG, R.I. 2003. Failed states, collapsed states, weak states: causes and indicators. (In Rotberg, R.I., ed. State failure and state weakness in a time of terror. Cambridge: World Peace Foundation. p. 1-25.)

ROTBERG, R.I. 2004. When states fail: causes and consequences. Princeton: Princeton University Press. 
SCHOLTE, J.A. 1999. The globalization of world politics. (In Baylis, J. \& Smith, S., eds. The globalization of world politics: an introduction to international relations. Oxford: Oxford University Press. p. 13-30.)

SCHUMPETER, J.A. 1947. Capitalism, socialism, and democracy. New York: Harper.

SPEISER, D. \& HANDY, P.S. 2005. The state, its failure and external intervention in Africa. Warwick: University of Warwick. (Centre for the Study of Globalisation and Regionalisation. Working Paper, No. 175/05.)

SUR, S. 2005. On "failed states" http://www.diplomatie.gouv.fr/fr/lMG/pdf/ 0502SUR-GB.pdf Date of access: 18 Jun. 2006.

TAKEYH, R. \& GVODSEV, N. 2003. Do terrorist networks need a home? (In Lennon, A.T.J., ed. The battle for hearts and minds: using soft power to undermine terrorist networks. Cambridge: MIT. p. 96.)

VINCENT, A. 2004. Conceptions of the state. (In Hawkesworth, M. \& Kogan, M., eds. Encyclopedia of government and politics. Vol. 1. London: Routledge. p. 39-53.)

VON HIPPEL, K. 2002. The roots of terrorism: probing the myths. The political quarterly, 73(1):25-39.

WESLEY-SMITH, T. 2004. Reinventing government: the politics of state failure and regional intervention in the pacific. Paper presented at a conference of the Regional Forum on Reinventing Government in the Pacific Islands, held in Apia, Samoa.

WILLIAMS, P.D. 2007. State failure in Africa: causes, consequences and responses: Africa South of the Sahara. London: Routledge. (Europe World Yearbook.)

WISE, W.M. 2004. American perspectives on the threat posed by weak and failing Asian states. Paper presented at the US-China Conference on Areas of Instability and Emerging Threats.

WOODWARD, S.L. 2004. Fragile states: exploring the concept. Paper presented at the States and Security Learning Group at the Peace and Social Justice Meeting of the Ford Foundation, Rio de Janeiro, Brazil.

ZARTMAN, I.W. 1995. Introduction: posing the problem of state collapse. (In Zartman, I.W., ed. Collapsed states: the disintegration and restoration of legitimate authority. Boulder: Rienner. p. 1-11.)

\section{Key concepts:}

failed state thesis

failed states: terrorist threat

liberal-democratic regime

Weberian ideal type state

\section{Kernbegrippe:}

liberaal-demokratiese regime

mislukte staattesis

mislukte state: terroriste bedreiging

Weberiaanse ideaaltipiese staat 